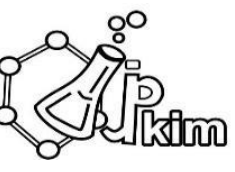

\title{
PENERAPAN MODEL PEMBELAJARAN THINK PAIR SHARE (TPS) PADA PEMBELAJARAN KIMIA UNTUK MENINGKATKAN KETERAMPILAN BERARGUMENTASI DAN MOTIVASI BELAJAR SISWA SMA
}

\author{
Fitri Wahyuning 1 , Erfan Priyambodo² dan Sugeng $^{3}$ \\ 1,2Universitas Negeri Yogyakarta \\ ${ }^{3}$ SMA Negeri 1 Wates
}

\section{A R T I C L E I N F O}

Article history: Received 23

Februari 2018 Received in revised form 23 Februari 2018 Accepted 12 Maret 2019 Available online 30 April 2019

Kata Kunci: Penelitian Tindakan Kelas, think pair share, motivasi belajar siswa

\begin{abstract}
Abstrak
Tujuan penelitian tindakan kelas ini adalah untuk mengetahui apakah penerapan model pembelajaran Think Pair Sharepada pembelajaran kimia dapat meningkatkan keterampilan berargumentasi dan motivasi belajar siswa di SMA N 1 Wates.Penelitian ini merupakan penelitian tindakan kelas yang dilaksanakan dalam tiga siklus, dimanasetiap siklus terdiri atas perencanaan, tindakan, pengamatan, dan refleksi.Hasil penelitian menunjukkan bahwa, penerapan model pembelajaran Think Pair Sharedapat meningkatkan keterampilan berargumentasi siswa dan motivasi belajar siswa. Persentase peningkatan observasi keterampilan berargumentasi pada siklus II aspek claim terjadi peningkatan sebesar 12,02 \% dari siklus I dan evidence terjadi peningkatan sebesar $12,74 \%$, sedangkan untuk aspek reason dikategorikan sedang meskipun sudah terjadi peningkatan 29,57\%. Persentase peningkatan pada siklus III terjadi sebesar 15,63\% pada aspek claim, sebesar $12,74 \%$ aspek evidence dan reason terjadi peningkatan sebesar $18,7 \%$. Persentase minat siswa, semangat siswa, tanggung jawab siswa, respon terhadap stimulus, serta rasa senang dan puas secara berturut-turut mengalami persentase peningkatan sebesar $9,81 \%, 6,34 \%, 6,73 \%, 6,73 \%$, dan $5,71 \%$.
\end{abstract}

\section{Abstract}

The purpose of this class action research is to find out whether the application of Think Pair Share learning models in chemistry learning can improve the argumentation skills and students' learning motivation in Wates N 1 High School. This research is a classroom action research conducted in three cycles, wherein each cycle consists of planning, action, observations, and reflections. The results of the study show that the application of Think Pair Shared learning models can improve students' argumentation skills and student motivation. The percentage increase in observation of argumentation skills in the second cycle of the claim aspect increased by $12.02 \%$ from the first cycle and the evidence increased by $12.74 \%$, while for the reason aspect was categorized as moderate even though there had been an increase of $29.57 \%$. The percentage increase in cycle III occurred by $15.63 \%$ in the claim aspect, by $12.74 \%$ in the evidence and reason aspect an increase of $18.7 \%$. The percentage of student interest, student enthusiasm, student responsibility, response to stimulus, and feeling of pleasure and satisfaction respectively experienced a percentage increase of $9.81 \%, 6.34 \%, 6.73 \%, 6.73 \%$, and $571 \%$. 


\section{PENDAHULUAN}

Proses pembelajaran kimia merupakan suatu upaya untuk memahamkan konsep kimia yang cenderung abstrak kepada siswa. Proses ini tentu saja menuntut keterampilan siswa untuk mengungkap konsep-konsep kimia tersebut melalui proses berpikir secara kritis (Wiyarsi \& Priyambodo, 2011).

Keberhasilan proses pembelajaran kimia juga tidak terlepas dari motivasi siswa untuk belajar kimia (Sutiman, Wiyarsi \& Priyambodo, 2014). Usaha meningkatkan motivasi belajar terkait erat dengan berbagai aspek dalam proses pembelajaran, seperti pengelola pembelajaran, model pembelajaran, lingkungan belajar dan lain sebagainya.

Salah satu model pembelajaran yang lazim dilaksanakan di sekolah adalah model kooperatif.Menurut Arends (2008) terdapat 4 pendekatan pokok dalam pembelajaran kooperatif, yaitu STAD (student team achievement divisions), jigsaw, GI (group investigation) dan pendekatan struktural. Pada akhirnya pendekatan struktural dikembangkan menjadi metode think-pair-shared dan numbered head together. Semua pendekatan dalam pembelajaran kooperatif tersebut memiliki sintaks tersendiri.Walaupun demikian, pembelajaran kooperatif menuntut masing-masing siswa untuk dapat menyampaikan hasil pemikirannya dalam kelompoknya. Dengan kata lain, diperlukan suatu kemampuan argumentasi untuk memfokuskan siswa belajar (Song \& Deane, 2014).

Hasil observasi peneliti pada proses pembelajarn kimia di SMA N 1 Wates, salah satu sekolah di kabupaten Kulonprogo DIY, menunjukkan bahwa guru sudah mengaktifkan siswa. Siswa dituntun berkelompok dalam pembelajaran kimia. Proses pembelajaran dalam setiap kelompok, siswa sudah menunjukkan keaktifan dalam belajar, namun untuk individu masih sulit memahami materi pembelajaran. Menurut wawancara guru, hasil nilai ulangan pembelajaran kimia siswa menunjukkan banyak yang belum tuntas dan dari hasil wawancara dengan beberapa siswa untuk materi kelas XI masih dianggap sulit.

Hasil analisis peneliti menyimpulkan bahwa terlalu banyak anggota dalam setiap kelompok juga dapat mempengaruhi kegiatan siswa dalam belajar, misalnya tidak semua siswa yang melakukan diskusi atau mengerjakan tugas yang diberikan oleh guru.Pada proses diskusi kelompok diharapkan semua siswa dapat berkomunikasi antar anggota kelompok, mengungkapkan pendapat atau argumennya, tidak melakukan aktivitas lain di luar pembelajaran, dan tidak hanya mengikuti pendapat teman. Berbeda argumen sudah biasa, karena setiap anak dapat memberikan penjelasan, pembuktian, dan alasan untuk setiap masalah yang ada.

Pada penelitian ini model pembelajaran Think Pair Share(TPS) diterapkan dalam pembelajaran kimia dengan harapan dapat meningkatkan motivasi belajar siswa dan juga kemampuan argumentasi siswa. Model pembelajaran Think Pair Share ini digunakan karena siswa hanya berpasangan dengan teman sebangku untuk mendiskusikan masalah yang diberikan guru, dan siswa diharapkan lebih fokus untuk termotivasi belajar.

\section{METODE PENELITIAN}

Penelitian yang dilakukan adalah Penelitian Tindakan Kelas. Tindakan yang direncanakan berupa penerapan model pembelajaran Think Pair Share pada pembelajaran kimia di SMAN 1 Wates untuk meningkatkan keterampilan berargumentasi dan motivasi belajar siswa.Subjek penelitian ini adalah siswa kelas XI MIA 3 SMAN 1 wates yang berjumlah 26 siswa, terdiri dari 7 siswa laki-laki dan 19 siswa perempuan. Objek penelitian adalah keterampilan berargumentasi dan motivasi belajar siswa dari penerapan pembelajaran model Think Pair Share. Teknik pengumpulan data yang digunakan dalam penelitian ini meliputi observasi atau pengalaman lapangan, kajian dokumen, dan angket. Data-data dari hasil penelitian diolah dan dianalisis secara kualitatif. Teknik analisis data secara kualitatif meliputi tiga komponen, yaitu reduksi data, penyajian data, dan penarikan kesimpulan serta verifikasi (Miles\& Huberman, 1992). Penelitian dikatakan berhasil apabila mampu mencapai kriteria yang telah ditentukan. Pada penelitian tindakan kelas ini, penelitian dikatakan berhasil apabila persentase indikator dalam keterampilan investigasi dan motivasi belajar siswa telah mencapai 75\% (Aqib, 2009).

\section{HASIL DAN PEMBAHASAN}

Penelitian tindakan kelas terdiri dari tiga siklus. Setiap siklus terdiri dari satu kali pertemuan. Materi pada siklus I adalah reaksi eksoterm dan endoterm, materi pada siklus II adalah kalorimeter, dan materi pada siklus III meliputi faktor yang mempengaruhi laju reaksi. Penelitian Tindakan Kelas dilaksanakan pada tanggal 26 September, 10 Oktober dan 8 November 2017. Setiap siklus dirancang melalui empat 
tahap yaitu perencanaan (planning), tindakan (acting), pengamatan (observing), dan refleksi (reflecting) (Kemmis \& McTaggart, 1990).

\section{Keterampilan Berargumentasi Siswa}

Teknik triangulasi data yang digunakan dalam keterampilan berargumentasi adalah penilaian dari LKS, observasi, dan wawancara. Hasil keterampilan argumentasi siswa dan motivasi belajar siswa disajikan dalam Tabel 1. Cara perhitungannya adalah sebagai berikut:

$$
\%=\frac{\text { Rerata skor yang diperoleh siswa }}{\text { Skor maksimal }} \times 100 \%
$$

Tabel 1Aspek Keterampilan Berargumentasi Siswa Siklus I, II dan III

\begin{tabular}{cccc}
\hline \multirow{2}{*}{ Aspek } & \multicolumn{3}{c}{ Siklus } \\
& I & II & III \\
\hline Claim & $69,47 \%$ & $81,49 \%$ & $97,12 \%$ \\
Evidence & $65,63 \%$ & $78,37 \%$ & $91,11 \%$ \\
Reason & $37,26 \%$ & $66,83 \%$ & $86,54 \%$ \\
\hline
\end{tabular}

Keterampilan berargumentasi yang diamati meliputi aspek claim (pernyataan yang menjawab permasalahan), evidence (data ilmiah yang mendukung jawaban dan aspek reason (siswa dapat memberikan alasan dari jawaban) (McNeill\& Krajcik,2006). Keterampilan tersebut dapat dijabarkan sebagai berikut:

1. Aspek Claim

Aspek claim atau pernyataan siswa dalam menjawab permasalahan dijabarkan dalam empat indikator. Indikator yang ditekankan dalam penelitian tindakan kelas ini adalah :

a. Siswa berpikir individu untuk menjawab pertanyaan atau permasalahan yang diberikan oleh guru

b. Siswa membuat pernyataan individu atas jawaban yang sudah didapat atau dapat dituliskan jawaban yang sudah diperoleh

c. Siswa melakukan percobaan/siswa mencari data pengamatan percobaan

d. Siswa membuat atau menuliskan data pengamatan dari percobaan.

Kenaikan persentase sebesar $12,02 \%$ pada siklus II dan $15,63 \%$ pada siklus III Hal ini menunjukkan bahwa siswa dapat menjawab permasalahan atau pertanyaan yang ada di LKS atau pertanyaan yang diajukan oleh guru. Pada siklus pertama aspek claim siswa dikategorikan sedang, sedangkan siklus II dan siklus III dikategorikan tinggi. Berdasarkan hasil refleksi siklus I untuk memfokuskan siswa dalam menjawab pertanyaan, guru membagi kelompok secara heterogen agar siswa tidak memilih teman saat akan duduk berkelompok.

\section{Aspek Evidence}

Indikator yang ditekankan dalam aspek evidence (siswa dapat mencari data ilmiah yang mendukung jawaban) penelitian tindakan kelas ini adalah :

a. Siswa mencari jawaban pertanyaan yang diberikan oleh guru dari berbagai sumber (buku, internet).

b. Siswa tertantang untuk mencari jawaban yang disertai dengan alasan yang kuat atau mendukung.

c. Siswa melakukan pengamatan saat percobaan berlangsung.

d. Siswa memiliki jawaban yang didukung dari sumber yang didapat dengan data yang relevan.

Berdasarkan Tabel 1 di atas dapat terlihat bahwa terjadi peningkatan persentase ketercapaian untuk aspek evidence sebesar 12,74 \% pada siklus II dan siklus III sebesar 12,74\%. Pada siklus pertama aspek evidence siswa termasuk kategori sedang. Pada siklus kedua dan ketiga, keterampilan evidence siswa termasuk kategori tinggi. Kenaikan persentase pada siklus III sebesar 12,74\% menunjukkan jika siswa sudah memiliki aspek evidence yang baik.

Pada siklus kedua dan ketiga, guru memberikan arahan kepada siswa untuk mencari data atau teori-teori yang sesuai dengan materi. Sehingga jawaban siswa didukung oleh data atau diperoleh dari sumber belajar yang didapat. 


\section{Aspek Reason}

Indikator aspek reason atau siswa dapat memberikan alasan dari jawaban yang ditekankan dalam penelitian ini adalah :

a. Siswa mengemukakan pendapat dengan alasan yang mendukung dalam sebuah diskusi kelompok

b. Siswa mampu menjawab pertanyaan saat diskusi dengan teman sekelompok atau kelompok lain

c. Siswa tertarik untuk mengomentari pendapat teman lain

d. Siswa menyimak dan memperhatikan kelompok lain yang maju ke depan dan memberi tanggapan berupa pertanyaan, masukan, maupun sanggahan.

Berdasarkan Tabel 1 di atas dapat terlihat bahwa terjadi peningkatan persentase ketercapaian untuk aspek reason dari 29,57\% pada siklus pertama menjadi 18,7\% pada siklus kedua.

Pada siklus pertama, aspek reason siswa termasuk kategori cukup. Pada siklus kedua, aspek reason siswa termasuk kategori sedang. Meskipun kenaikan persentase pada siklus II sebesar 29,57\% namun belum tercapai target yang diinginkan, yaitu 75\%. Hasil tersebut didukung oleh McNeill dan Kracjik (2006) yang menyatakan bahwa komponen dalam argumentasi yang paling sulit bagi siswa adalah reasoning atau memberi alasan. Sebagian besar argumentasi siswa berupa pernyataan yang memuat sedikit alasan pendukung.

Pada siklus ketiga, guru memberikan LKS berbasis masalah dalam kehidupan sehari-hari kepada siswa. Sehingga waktu yang digunakan untuk mengerjakan secara mandiri kemudian berkelompok pasangan lebih banyak dibandingkan pembelajaran pada siklus II dan III. Pada pembelajaran I dan II metode yang digunakan dalam pembelajaran adalah pratikum/eksperimen, sehingga waktu yang digunakan siswa untuk berdiskusi dengan teman sebangku lebih sedikit, karena pratikum membutuhkan waktu yang lebih banyak. Sehingga siswa kegiatan siswa kurang aktif dalam melakukan diskusi tanya jawab, dimana terjadi perbedaan pendapat dan mereka dapat mengemukaan pendapatnya masing-masing.

\section{Motivasi Belajar Siswa}

Dilihat dari materi pembelajaran juga sangat mempengaruhi peningkatan keterampilan berargumentasi dan motivasi belajar siswa. Materi termokimia (reaksi eksoterm, reaksi endoterm dan kalorimeter) lebih sulit dibandingkan dengan materi laju reaksi. Materi laju reaksi lebih berbasis mengenai permasalahan yang ada di kehidupan sehari-hari, sehingga siswa lebih cepat mudah menerima materi pembelajaran. Hal ini juga berdasarkan angket motivasi siswa dari proses pembelajaran pratindakan dan siklus akhir, terdapat peningkatan dari lima indikator motivasi belajar siswa.

Teknik pengambilan data yang digunakan dalam motivasi belajar siswa adalah angket motivasi dan wawancara, kemudian peneliti mengambil satu teknik yang dijadikan penilaian utama dalam mengambil data motivasi belajar siswa. Teknik penilaian yang dipilih adalah penilaian angket motivasi yang dilakukan oleh siswa sebelum tindakan pembelajaran menggunakan model pembelajaran Think Pair Share dan siklus akhir atau siklus III setelah menerapkan model pembelajaan Think Pair Share. Ada lima indikator yang mempengaruhi motivasi belajar, yaitu minat dan perhatian siswa terhadap pelajaran, semangat siswa untuk melakukan tugas-tugas belajarnya, tanggungjawab siswa dalam mengerjakan tugas-tugas belajarnya, reaksi yang diberikan siswa terhadap stimulus yang diberikan guru dan rasa senang dan puas terhadap tugas yang diberikan (Sudjana, 2009).

Tabel2. Indikator Motivasi Belajar Siswa

\begin{tabular}{lcc}
\hline \multicolumn{1}{c}{ Indikator } & $\begin{array}{c}\text { Pra- } \\
\text { tindakan }\end{array}$ & $\begin{array}{c}\text { Siklus } \\
\text { Akhir }\end{array}$ \\
\hline $\begin{array}{l}\text { Minat dan perhatian } \\
\text { siswa terhadap } \\
\text { pelajaran }\end{array}$ & $73,26 \%$ & $83,07 \%$ \\
$\begin{array}{l}\text { Semangat siswa untuk } \\
\text { melakukan tugas - } \\
\text { tugas belajarnya }\end{array}$ & $69,42 \%$ & $75,76 \%$ \\
$\begin{array}{l}\text { Tanggung jawab dalam } \\
\text { mengerjakan tugas - } \\
\text { tugas belajarnya }\end{array}$ & $69,61 \%$ & $76,34 \%$ \\
\hline
\end{tabular}




\begin{tabular}{lcc}
\hline $\begin{array}{l}\text { Reaksi yang } \\
\text { ditunjukkan siswa }\end{array}$ & $70 \%$ & $76,73 \%$ \\
terhadap stimulus yang & & \\
diberikan oleh guru & & \\
$\begin{array}{l}\text { Rasa senang dan puas } \\
\text { dalam mengerjakan }\end{array}$ & $71,73 \%$ & $77,5 \%$ \\
tugas yang diberikan & & \\
\hline
\end{tabular}

Indikator motivasi belajar siswa tersebut dapat dijabarkan sebagai berikut

1. Minat dan perhatian siswa terhadap pelajaran

Item observasi yang ditekankan dalam penelitian tindakan kelas ini adalah siswa aktif memperhatikan penjelasan guru selama kegiatan pembelajaran dan siswa antusias mengikuti pembelajaran kimia. Peningkatan persentase minat dan perhatian siswa dari 73,26 \% pada pratindakan menjadi 83,07 \% pada siklus akhir.

Kenaikan persentase sebesar 9,81 \% menunjukkan jika minat dan perhatian siswa terhadap pelajaran meningkat. Pada pembelajaran dengan menggunakan model Think Pair Share dan melaksanakan praktikum, antusias siswa dalam mengikuti pembelajaran kimia meningkat. Hal ini ditunjukkan dengan siswa menjadi inisiatif menanggapi penjelasan dan pertayaan yang disampaikan oleh guru.

2. Semangat siswa untuk melakukan tugas-tugas belajarnya

Item observasi yang ditekankan dalam penelitian tindakan kelas ini adalah siswa aktif berdiskusi kelompok dalam menyelesaikan tugas yang diberikan oleh guru dan siswa tekun dalam mengerjakan tugas yang diberikan oleh guru. Peningkatan persentase semangat siswa dari 69,42\% pada pratindakan menjadi $75,76 \%$ pada siklus akhir setelah melaksanakan model pembelajaran menggunakan Think Pair Share.

Kenaikan persentase sebesar 6,34\% menunjukkan jika semangat siswa untuk melakukan tugastugas belajarnya meningkat. Pada pembelajaran dengan menggunakan model Think Pair Share siswa dibagi LKS individu untuk dikerjakan sendiri terlebih dahulu kemudian didiskusikan dengan teman. Sehingga, ketika menemui kesulitan dalam mengerjakan tugas yang diberikan oleh guru, siswa aktif mencari referensi dari berbagai sumber baik buku maupun internet dan tidak ragu untuk bertanya kepada guru maupun teman.

3. Tanggungjawab siswa dalam mengerjakan tugas-tugas belajarnya

Item observasi yang ditekankan dalam penelitian tindakan kelas ini adalah siswa berusaha menyelesaikan tugas kelompok dengan penuh tanggungjawab dan siswa mengumpulkan laporan praktikum tepat waktu.Peningkatan persentase tanggungjawab siswa dari $69,61 \%$ pada pratindakan menjadi $76,34 \%$ pada siklus akhir.

Kenaikan persentase sebesar 6,73\% menunjukkan jika tanggungjawab siswa dalam mengerjakan tugas-tugas belajarnya meningkat. Setelah mengikuti pembelajaran, setiap siswa mengumpulkan LKS yang telah dikerjakan.

4. Reaksi yang diberikan siswa terhadap stimulus yang diberikan guru

Item observasi yang ditekankan dalam penelitian tindakan kelas ini adalah siswa aktif bertanya kepada guru atau teman mengenai materi yang belum dipahami dan siswa mencari serta menemukan jawaban dari pertanyaan yang diajukan oleh guru. Peningkatan persentase reaksi yang diberikan siswa terhadap stimulus yang diberikan guru dari $70 \%$ pada pratindakan menjadi $76,73 \%$ pada siklus akhir.

Kenaikan persentase sebesar 6,73\% menunjukkan jika reaksi siswa terhadap stimulus yang diberikan guru meningkat. Pada pembelajaran dengan menggunakan model pembelajaran Think Pair Share, siswa diarahkan secara mandiri untuk mengerjakan LKS.

5. Rasa senang dan puas terhadap tugas yang diberikan

Item observasi yang ditekankan dalam penelitian tindakan kelas ini adalah siswa aktif membaca buku untuk mencari sumber jawaban yang benar dan tidak mudah putus asa dalam mengerjakan tugas yang diberikan oleh guru. Peningkatan persentase rasa senang dan puas siswa dari $71,73 \%$ pada pratindakan menjadi $77,5 \%$ pada siklus akhir. Kenaikan persentase sebesar 5,77\% menunjukkan jika rasa senang dan puas siswa terhadap tugas yang diberikan meningkat. 


\section{SIMPULAN DAN SARAN}

Dari hasil penelitian maka dapat disimpulkan bahwa: (1) Penerapan model pembelajaran Think Pair Share dapat meningkatkan keterampilan berargumentasi siswa di SMAN 1 Wates kelas XI MIA 3. Keterampilan berargumentasi pada penelitian ini meliputi aspek claim, evidence dan reason. (2) Penerapan model pembelajaran Think Pair Share juga dapat meningkatkan motivasi belajar siswadi SMAN 1 Wates kelas XI MIA 3.

\section{DAFTAR PUSTAKA}

Aqib, Z. (2009). Penelitian Tindakan Kelas. Bandung: Yrama Widya.

Jayadiningrat, Made Gautama, and Emirensia K. Ati. "Peningkatan Keterampilan Memecahkan Masalah Melalui Model Pembelajaran Problem Based Learning (PBL) Pada Mata Pelajaran Kimia." Jurnal Pendidikan Kimia Indonesia 2.1 (2018): 1-7.

Kemmis, S dan Mc. Taggart, R. (1990). The Action Research Reader. Third Edition (substantially revised). Victoria: Deakin University Pers

McNeill, K.L., \& Krajcik, J. (2006). Middle School Students' Use of Appropriate and Inappropriate Evidence in Writing Scientific Explanations. Proceedings of the 33rd Carnegie Symposium on Cognition.

Miles, M., \& Huberman A.M. (1992). Analisis Data Kualitatif. Jakarta: UI Press.

Song, Y., \& Deane, P. (2014). A CaseStudyin Principled Assessment Design: Designing assessments to Measure and Support the Development of Argumentative Reading and Writing Skills. Psicologia Educativa.

Sudjana, N. (2009). Penilaian Hasil Proses Belajar Mengajar. Bandung: Rosda Karya.

Surayya, Lina, et al. "Pengaruh model pembelajaran think pair share terhadap hasil belajar IPA ditinjau dari keterampilan berpikir kritis siswa." Jurnal Pendidikan dan Pembelajaran IPA Indonesia 4.1 (2014).

Sutiman, S., Wiyarsi, A. \& Priyambodo,E. (2014). Efektivitas Pembelajaran Kooperatif dalam Meningkatkan Aktivitas dan Motivasi Belajar Mahasiswa pada Perkuliahan Filsafat Ilmu.Jurnal Pendidikan Matematika dan Sains, 2(1), 51-64.

Sunarto, Wisnu, Woro Sumarni, and Eli Suci. "Hasil belajar kimia siswa dengan model pembelajaran metode Think-Pair-Share dan metode ekspositori." Jurnal inovasi pendidikan kimia 2.1 (2008).

Wiyarsi, A. \& Priyambodo, E. (2011). Efektivits Penerapan Penilaian Proyek (Project based Assessment) pada Pembelajaran Kimia terhadap Kemampuan Berpikir Kritis dan Ketuntasan Belajar Kimia Siswa SMA di Sleman. Prosiding Seminar Nasional Kimia UNESA 2011 